\title{
Identification of a novel frameshift mutation (L345Sfs*15) in a Korean neonate with methylmalonic acidemia
}

\author{
Young A Kim ${ }^{1,+}$, Ji-Yong Kim ${ }^{1,+}$, Yoo-Mi Kim¹, and Chong Kun Cheon ${ }^{1,2, *}$ \\ 'Department of Pediatrics, Pusan National University Children's Hospital, Pusan National University School of Medicine, Yangsan, Korea \\ ${ }^{2}$ Research Institute for Convergence of Biomedical Science and Technology, Pusan National University Yangsan Hospital, Yangsan, Korea
}

\begin{abstract}
Methylmalonic acidemia (MMA) is an autosomal recessive metabolic disorder characterized by an abnormal accumulation of methylmalonyl-CoA and methylmalonate in body fluids without hyperhomocysteinemia. Cardiac disease is a rarely known lethal complication of MMA, herein, we report a Korean neonate diagnosed with MMA on the basis of biochemical and genetic findings, who developed cardiomyopathy, resulting in sudden death. The patient presented vomiting and lethargy at 3 days of age. Initially, the patient had an increased plasma propionylcarnitine/acetylcarnitine concentration ratio of 0.49 in a tandem mass spectrometry analysis and an elevated ammonia level of $537 \mu \mathrm{mol} / \mathrm{L}$. Urine organic acid analysis showed increased excretion of methylmalonate. Subsequent sequence analysis of the methylmalonyl-CoA mutase (MUT) gene revealed compound heterozygous mutations c.323G>A (p.Arg108His) in exon 1 and c.1033_1034del (p. Leu345Serfs*15) in exon 4, the latter being a novel mutation. In summary, this is the first case of MMA and cardiomyopathy in Korea that was confirmed by genetic analysis to involve a novel MUT mutation.
\end{abstract}

Key words: Methylmalonic acidemia, Cardiomyopathies, MUT gene.

\section{Introduction}

Methylmalonic acidemia (MMA, MIM \#251000) is an inborn error of metabolism that is biochemically characterized by accumulation of methylmalonate in urine and other body fluids $[1,2]$. MMA can be caused by a defect either in the activity of the methylmalonyl-CoA mutase (MCM, MIM\#51000), which catalyzes the reversible isomerization of L-methylmalonyl-CoA to succinyl-CoA, or in the synthesis of its cofactor, 5-deoxyadenosyl-cobalamin (cblA, cblB, cblC, cblD variant-2 complementation groups coded by MMAA, MMAB, MMACHC and MMADHC) [1,3]. The deficiencies of MCM are further subdivided into mut ${ }^{0}$, which indicates complete deficiency, and mut ${ }^{-}$, which indicates partial deficiency [4]. MMA has been associated with various clinical phenotypes ranging from a benign condition to fatal neonatal disease [5]. Patients with mut ${ }^{0}$ often present ketoacidosis, lethargy, repeated vomiting, coma or even death, in the newborn period, and suffer from severe long-term complications such as renal failure and neurological impairments. On the other hand, patients with mut have a lower occurrence of mortality, morbidity, and long-term complications [5]. Cardiac disease is a known, yet rare, lethal complication of MMA [6,7] and it has been scarcely reported in the Asian population [7]. We report herein a novel MUT gene mutation in a Korean newborn with

Received: 31 October 2017, Revised: 24 November 2017, Accepted: 2 December 2017, Published: 31 December 2017

*Corresponding author: Chong Kun Cheon, M.D., Ph.D.

Department of Pediatrics, Pusan National University Children's Hospital, Pusan National University School of Medicine, 20 Geumo-ro, Mulgeum-eup, Yangsan 50612, Korea.

Tel: +82-55-360-3158, Fax: +82-55-360-2181, E-mail: chongkun@pusan.ac.kr

${ }^{\dagger}$ These authors contributed equally to this work as co-first authors.

Conflict of interest: The authors declare that they do not have any conflicts of interest.

(c) This is an open-access article distributed under the terms of the Creative Commons Attribution Non-Commercial License (http://creativecommons.org/licenses/by-nc/4.0/) which permits unrestricted non-commercial use, distribution, and reproduction in any medium, provided the original work is properly cited.

(c) Copyright 2017 by the Korean Society of Medical Genetics and Genomics 
MMA and cardiomyopathy, and review the relevant literature.

\section{Case}

A 3-day-old, female newborn presented vomiting and lethargy. The patient was born to healthy, non-consanguineous Korean parents as their first baby at 40 weeks of gestation. Pregnancy was uneventful and she was delivered spontaneously with a birth weight of $3,090 \mathrm{~g}$ (25th-50th percentile). Head circumference was $38 \mathrm{~cm}$ (>97th percentile) and height was 53 $\mathrm{cm}$ (75th-90th percentile). At 3 days of age, she was transferred to our hospital. With deterioration of self-respiration, she underwent ventilator care. Initial investigations showed she had a total leukocyte count of $3,400 / \mathrm{mm}^{3}$, hemoglobin levels of $17.9 \mathrm{~g} / \mathrm{dL}$, and a platelet count of $210,000 / \mathrm{mm}^{3}$. Arterial blood gas analysis revealed a $\mathrm{pH}$ of $7.29, \mathrm{PaCO}_{2}$ of $15 \mathrm{mmHg}, \mathrm{HCO}^{3-}$ of $12.4 \mathrm{mmol} / \mathrm{L}$, and a base excess of -18.2 , suggesting metabolic acidosis. Other laboratory results were ammonia of 537 (reference range $[R R],<50) \mu \mathrm{mol} / \mathrm{L}$, glycine of $320.4(R R, 232-740)$ $\mathrm{nmol} / \mathrm{mL}$, aspartate transaminase of $111(\mathrm{RR},<40) \mathrm{IU} / \mathrm{L}$, alanine transaminase of $27\left(R R_{1}<40\right) \mathrm{IU} / \mathrm{L}$, and lactic acid of $4(\mathrm{RR}, 0.5$ 2.2) $\mathrm{mmol} / \mathrm{L}$. Chest radiography showed no specific findings with cardiothoracic (CT) ratio of 0.41 (Fig. 1A). Echocardiography demonstrated good ventricular function with a small secundum atrial septal defect. Initial tandem mass spectrometry (MS/MS) analysis revealed an increased propionylcarnitine (C3)/acetylcarnitine (C2) concentration ratio of 0.49 ( $R R, 0.00-0.40)$. A urinary organic acid test revealed a marked increase in methylmalonate excretion of $884.9\left(R R_{1}<5\right) \mathrm{mmol} / \mathrm{mol} \mathrm{Cr}$, with an increased 3-hydroxypropionate excretion of $44.4\left(R_{1},<19\right) \mathrm{mmol} / \mathrm{mol}$ $\mathrm{Cr}$. Based on the MS/MS and organic acid analysis, a presump- tive diagnosis of MMA was made. Emergency treatment was performed during the acute metabolic crisis, including administration of sodium benzoate, phenylbutyrate, and continuous renal replacement therapy (CRRT) on the day of admission. On the 5 th day of age, the level of blood ammonia had decreased to $130 \mu \mathrm{mol} / \mathrm{L}$, so CRRT was stopped. Having completely recovered from the acute metabolic crisis, the patient was released at 2 weeks age with a low protein diet and medications including sodium benzoate ( $450 \mathrm{mg} / \mathrm{kg} /$ day), phenylbutyrate $(450 \mathrm{mg} / \mathrm{kg} /$ day) and L-carnitine (100 mg/kg/day). After discharge, she did not experience any further attacks. However, she was unexpectedly found cardiopulmonary arrest at 4 months of age without any signs of illness or metabolic crisis. Echocardiography was performed at the emergency room and revealed dilated, hypokinetic cardiac chambers, indicating cardiomyopathy. Chest radiography showed cardiomegaly with CT ratio of 0.56 , which was suspected cardiomyopathy (Fig. 1B). Because of the patient's condition, laboratory evaluation could not be performed. Seven days before the event, ammonia level was $95 \mu \mathrm{mol} / \mathrm{L}$ on routine check-up. Despite aggressive resuscitation, her condition deteriorated rapidly, and she died in a day.

Genomic DNA was extracted from the family trio. Direct sequencing of all the coding exons, including flanking introns of MUT, was performed. Informed consent was obtained from the parents of the patient. Sequence analysis of the MUT gene revealed a $\mathrm{G} \rightarrow \mathrm{A}$ transition mutation at $M U T \mathrm{CDNA}$ nucleotide position 323 (p.Arg 108His) in exon 1, which has already been reported. The other mutation, a 2-bp small deletion mutation in exon 4 (c.1033_1034del), caused a frameshift starting at codon 345 , leading to a premature stop codon, which has never been reported (Fig. 2A). The former mutation was derived from the
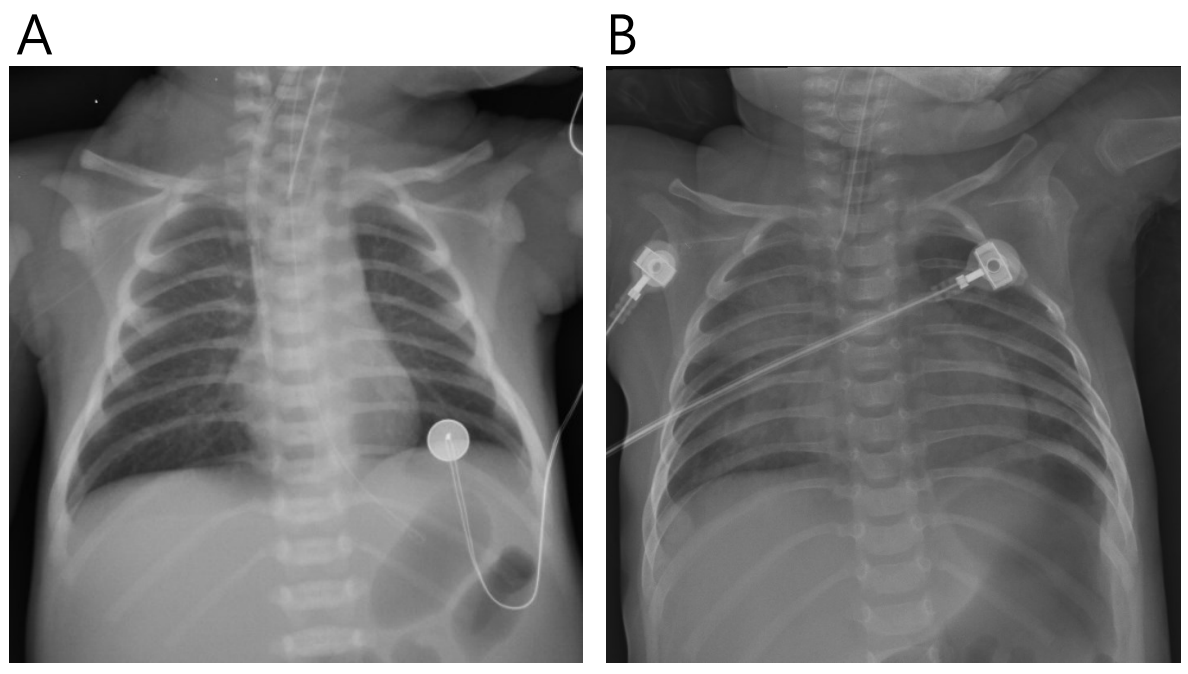

Fig. 1. Antero-posterior chest radiographs of the patient. (A) Initial chest radiograph shows no abnormal findings with cardiothoracic ratio of 0.41 at 3 days of age. (B) On the day of cardiopulmonary arrest, chest radiograph demonstrates cardiomegaly with cardiothoracic ratio of 0.56 and pulmonary infiltrates on both lung fields, which were thought to be secondary changes due to resuscitation. 


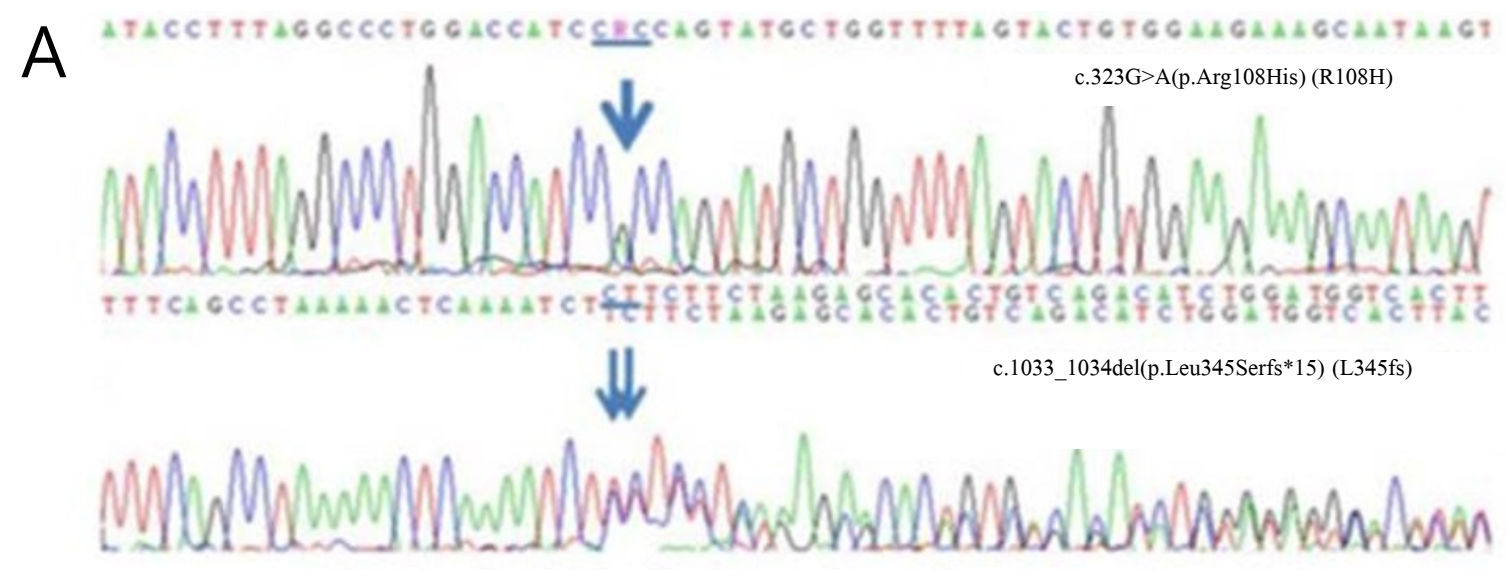

c.[323G>A];[1033_1034del] (p.[Arg108His];[Leu345Serfs*15])

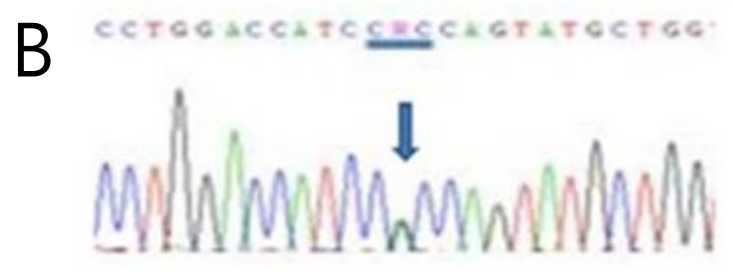

Father: Heterozygote carrier of c.323G $>$ A(p.Arg108His)

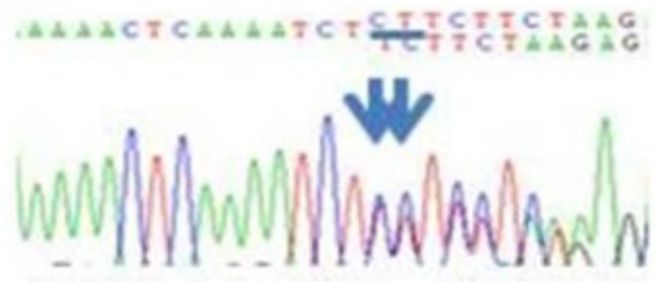

Mother: Heterozygote carrier of c.1033_1034del(p.Leu345Serfs*15)

Fig. 2. Partial genomic DNA sequence of the MUT gene of the patient and her parents. (A) The patient had compound heterozygous mutations including a missense mutation (p.Arg108His) and a frameshift mutation (p.Leu345Serfs $\left.{ }^{\star} 15\right)$. (B) Patient's father is a heterozygous carrier of p.Arg108His and his mother is a heterozygous carrier of p.Leu345Serfs ${ }^{\star} 15$.

father, and the latter mutation was derived from the mother (Fig. 2B).

\section{Discussion}

The described case was diagnosed as early-onset MMA exhibiting a mut ${ }^{0}$ phenotype based on clinical manifestations, and biochemical and genetic analysis. Initially, the patient had an increased $\mathrm{C} 3 / \mathrm{C} 2$ concentration ratio of 0.49 , as revealed by tandem MS/MS analysis, and an elevated ammonia level of $537 \mu \mathrm{mol} / \mathrm{L}$, which is suggestive of MMA. It is very important to identify affected neonates immediately, when there are abnormal laboratory results regarding MMA in newborn screening. Cheng et al. [8] reported that referred newborns with elevated plasma C3/C2 ratios $>0.4$, and ammonia levels $>200 \mu \mathrm{mol} / \mathrm{L}$, should be highly suspected of having MMA.

Unfortunately, we could not check the patient's enzyme activity owing to technical limitations. Therefore, we performed the MUT genetic analysis. Ultimately, we identified a compound heterozygous missense mutation, c.323G >A (p.Arg 108His), in exon
1, and a frameshift mutation, c.1033_1034del (p.Glu228Lys), in exon 4. To date, a total of 201 different mutations of the MUT gene have been listed on the Human Gene Mutation Database (http://www.hgmd.org), demonstrating the highly pleiomorphic nature of this condition; there are 138 missense/nonsense mutations, 27 small deletion mutations, 20 mis-splicing mutations, 12 small insertion mutations, 3 small INDELs mutations, and 1 gross deletion mutation. Mutations in the MUT gene have been identified in 17 Korean patients, and these were comprised of 17 different mutations (Table 1) [9-12]. The MUT mutations that show poor outcome in the Korean population are p.[Arg 108Cys]; [Leu345Serfs*15], p. [Gly94Glu];[Arg369Cys], p.[Arg369His];[Arg369His], p.[Arg 108Cys]; [Arg 108His], p. [Arg228*];[Leu494*], p.[Arg31*];[p.Glu117*], and p.[Leu494*]; [Arg 108His] $[9,10]$. The p.Arg 108His mutation is relatively common in Korean patients [10], which causes severe metabolic crisis or developmental delay. The p.Gly94Glu mutation was only found in Korean patients with MMA [9]. The p.Arg369His mutation was identified in Korean patients with MMA, Japanese patients with MMA, and an American patient with MMA $[9,13,14]$. The 
Table 1. Summary of mutation analysis in patients with methylmalonic acidemia in the Korean population

\begin{tabular}{|c|c|c|c|c|c|c|c|}
\hline Case & Classification & Gene & Exon & Nucleotide change & Protein change & Outcome & Reference \\
\hline 1 & NA & MUT & $\begin{array}{l}\text { IV } \\
\text { I }\end{array}$ & $\begin{array}{l}\text { c.1033_1034del }{ }^{\mathrm{a}} \\
\text { c.323G>A }\end{array}$ & $\begin{array}{l}\text { p.Leu345Serfs }{ }^{*} 15 \\
\text { p.Arg108His }\end{array}$ & Cardiomyopathy $\rightarrow$ expired & This case \\
\hline 2 & NA & MUT & $\begin{array}{l}\mathrm{VI} \\
\|\end{array}$ & $\begin{array}{l}\text { c.1106G }>\text { A } \\
\text { c.362_368dupAGTTCTA }\end{array}$ & $\begin{array}{l}\text { p.Arg369His } \\
\text { p.Tyr123* }\end{array}$ & NA & Song et al. [12] (2015) \\
\hline 3 & NA & MUT & $\begin{array}{l}\| \\
\text { VIII }\end{array}$ & $\begin{array}{l}\text { c. } 323 G>A \\
\text { c. } 1672+2 T>C(\text { IVS } 8(+2) T>C\end{array}$ & p.Arg108His & $\begin{array}{l}\text { Asymptomatic } \\
\rightarrow \text { normal development }\end{array}$ & Kwak and Kim [11] (2014) \\
\hline 4 & NA & MUT & $\begin{array}{c}\text { V } \\
\text { VIII }\end{array}$ & $\begin{array}{l}\text { C. } 1031 T>A \\
\text { C. } 1481 T>A\end{array}$ & $\begin{array}{l}\text { p.Ser344Tyr } \\
\text { p.Leu494* }\end{array}$ & Normal development & Lee et al. [10] (2008) \\
\hline 5 & NA & MUT & $\begin{array}{c}\| \\
X I \|\end{array}$ & $\begin{array}{l}\text { c. } 356 G>A \\
\text { c. } 2179 C>T\end{array}$ & $\begin{array}{l}\text { p.Ser119Asn } \\
\text { p.Arg727* }\end{array}$ & Normal development & Lee et al. [10] (2008) \\
\hline 6 & NA & MUT & $\begin{array}{l}\text { III } \\
\text { VIII }\end{array}$ & $\begin{array}{l}\text { c. } 682 C>T \\
\text { c. } 1481 T>A\end{array}$ & $\begin{array}{l}\text { p.Arg } 228^{*} \\
\text { p.Leu } 494^{*}\end{array}$ & $\begin{array}{l}\text { Severe metabolic crisis } \\
\rightarrow \text { developmental delay }\end{array}$ & Lee et al. [10] (2008) \\
\hline 7 & NA & MUT & $\begin{array}{l}\| \\
\|\end{array}$ & $\begin{array}{l}\text { c.91C }>\mathrm{T} \\
\text { c.349G>T }\end{array}$ & $\begin{array}{l}\text { p.Arg31* } \\
\text { p.Glu117* }\end{array}$ & Developmental delay & Lee et al. [10] (2008) \\
\hline 8 & NA & MUT & $\begin{array}{l}\| \\
\|\end{array}$ & $\begin{array}{l}\text { C. } 91 \mathrm{C}>\mathrm{T} \\
\text { c.349G>T }\end{array}$ & $\begin{array}{l}\text { p.Arg31* } \\
\text { p.Glu117* }\end{array}$ & Normal development & Lee et al. [10] (2008) \\
\hline 9 & NA & MUT & $\begin{array}{l}\| \\
\|\end{array}$ & $\begin{array}{l}\text { c. } 322 \mathrm{C}>\mathrm{T} \\
\text { c. } 323 \mathrm{G}>\mathrm{A}\end{array}$ & $\begin{array}{l}\text { p.Arg108Cys } \\
\text { p.Arg108His }\end{array}$ & $\begin{array}{l}\text { Severe metabolic crisis } \\
\rightarrow \text { expired }\end{array}$ & Lee et al. [10] (2008) \\
\hline 10 & NA & MUT & $\begin{array}{l}\| \\
\text { VI }\end{array}$ & $\begin{array}{l}\text { c. } 349 G>T \\
\text { c. } 1105 C>T\end{array}$ & $\begin{array}{l}\text { p.Glu117* } \\
\text { p.Arg369Cys }\end{array}$ & Normal development & Lee et al. [10] (2008) \\
\hline 11 & NA & MUT & $\begin{array}{l}\| \\
\|\end{array}$ & $\begin{array}{l}\text { c. } 322 \mathrm{C}>\mathrm{T} \\
\text { c. } 323 \mathrm{G}>\mathrm{A}\end{array}$ & $\begin{array}{l}\text { p.Arg108Cys } \\
\text { p.Arg108His }\end{array}$ & $\begin{array}{l}\text { Severe metabolic crisis } \\
\rightarrow \text { expired }\end{array}$ & Lee et al. [10] (2008) \\
\hline 12 & NA & MUT & $\begin{array}{c}\| \\
V I I I\end{array}$ & $\begin{array}{l}\text { c.349G>T } \\
\text { c.1505_61del }\end{array}$ & $\begin{array}{l}\text { p.Glu117* } \\
\text { p.Val502Aspfs*11 }\end{array}$ & Normal development & Lee et al. [10] (2008) \\
\hline 13 & NA & MUT & $\begin{array}{l}\text { VIII } \\
\|\end{array}$ & $\begin{array}{l}\text { c. } 1481 \mathrm{~T}>\mathrm{A} \\
\text { c. } 323 \mathrm{G}>\mathrm{A}\end{array}$ & $\begin{array}{l}\text { p.Leu } 494^{*} \\
\text { p.Arg108His }\end{array}$ & Developmental delay & Lee et al. [10] (2008) \\
\hline 14 & NA & MMACHC & IV & $\begin{array}{l}\text { c. } 482 \mathrm{G}>\mathrm{A} \\
\text { c.566_574del }\end{array}$ & $\begin{array}{l}\text { p.Arg161Gln } \\
\text { p.Arg189_Ala191del }\end{array}$ & $\begin{array}{l}\text { Severe metabolic crisis } \\
\rightarrow \text { normal development }\end{array}$ & Lee et al. [10] (2008) \\
\hline 15 & NA & MMACHC & IV & $\begin{array}{l}\text { c. } 482 G>A \\
\text { c. } 609 G>A\end{array}$ & $\begin{array}{l}\text { p.Arg161Gln } \\
\text { p.Trp203* }\end{array}$ & $\begin{array}{l}\text { Developmental delay } \\
\rightarrow \text { normal development }\end{array}$ & Lee et al. [10] (2008) \\
\hline 16 & Mut $^{0}$ & MUT & $\begin{array}{l}\| \\
\text { VI }\end{array}$ & $\begin{array}{l}\text { c. } 357 G>A \\
\text { c. } 1181 C>T\end{array}$ & $\begin{array}{l}\text { p.Gly94Glu } \\
\text { p.Arg369Cys }\end{array}$ & $\begin{array}{l}\text { Severe metabolic crisis } \\
\rightarrow \text { expired }\end{array}$ & Jung et al. [9] (2005) \\
\hline 17 & Mut $^{0}$ & MUT & $\begin{array}{l}\| \\
\text { VI }\end{array}$ & $\begin{array}{l}\text { c. } 357 G>A \\
\text { c. } 1181 C>T\end{array}$ & $\begin{array}{l}\text { p.Gly94Glu } \\
\text { p.Arg369Cys }\end{array}$ & $\begin{array}{l}\text { Severe metabolic crisis } \\
\rightarrow \text { normal development }\end{array}$ & Jung et al. [9] (2005) \\
\hline 18 & Mut $^{0}$ & MUT & V & c. $1117 \mathrm{C}>\mathrm{A}$ & p.Ser344Tyr & Mild developmental delay & Jung et al. [9] (2005) \\
\hline 19 & NA & MUT & $\begin{array}{l}\text { III } \\
\text { III }\end{array}$ & $\begin{array}{l}\text { c. } 643 \mathrm{~T}>\mathrm{G} \\
\text { c. } 765 \mathrm{C}>\mathrm{T}\end{array}$ & $\begin{array}{l}\text { p.Asn189Lys } \\
\text { p.Thr230lle }\end{array}$ & Mild developmental delay & Jung et al. [9] (2005) \\
\hline 20 & NA & MUT & VI & c. $1182 G>A$ & p.Arg369His & $\begin{array}{l}\text { Severe metabolic crisis } \\
\rightarrow \text { expired }\end{array}$ & Jung et al. [9] (2005) \\
\hline
\end{tabular}

${ }^{a}$ Novel mutation.

$\mathrm{NA}$, not available. 
p.Leu 494* mutation was found in compound heterozygous Japanese and Korean patients with MMA $[10,15]$. The p.Glu117* has been found with a high prevalence in Japanese and Korean patients with MMA $[16,17]$. A novel p.Leu345Serfs*15 mutation identified in the coding region in the present study occurs within the $\beta / \alpha$ barrel domain and may produce a truncated polypeptide that contains only the barrel domain and thus yield an inactive protein. Structural analyses of the mutated protein showed missing amino acids in the truncated protein (Fig. 3) and revealed major changes in its tertiary structure due to the deleted region (THR359-VAL750) and cutting C-terminus that will affect the cofactor 5-deoxyadenosyl-cobalamin-binding site, which causes the protein to be dysfunctional. It seems that the vast alteration in the structure of the protein causes great impacts on its function owing to its strong correlation with the protein tertiary structure.

A few report of cardiac disease in MMA patients have been found in the literature. To date, seven patients (2 Caucasian, 1 Moroccan and 4 Japanese) with MMA and cardiomyopathy have been reported, and 4 of them died because of cardiomyopathy $[6,7]$. And one Arab patient with MMA was reported to have been treated for heart failure due to suspected carnitine deficiency [18]. Our patient was supplemented with adequate

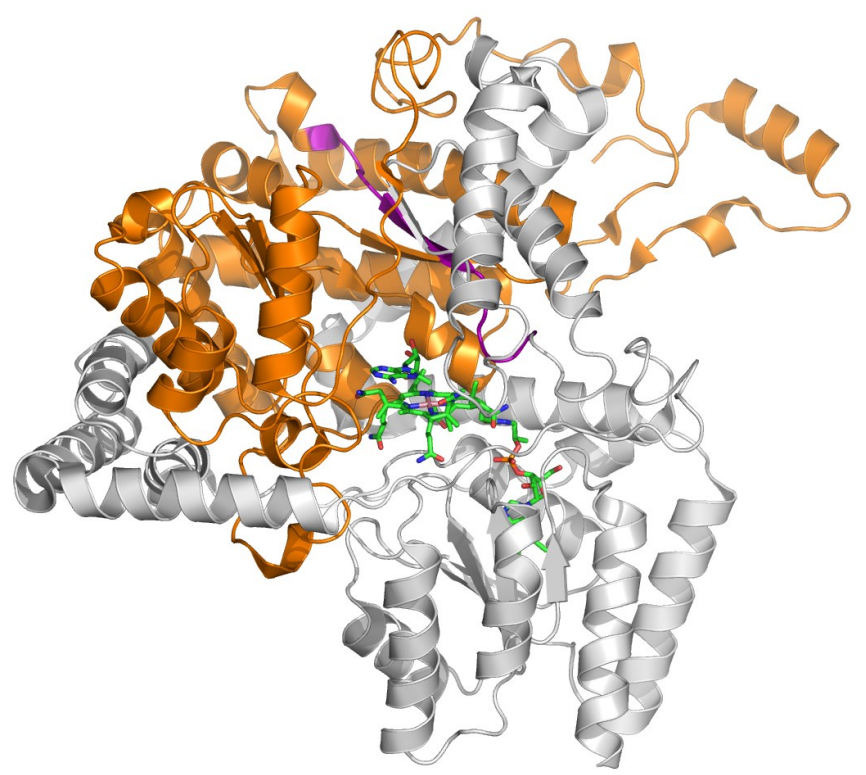

Fig. 3. X-ray crystal structure of human methylmalonyl-coA mutase (MCM) model built on the basis of the experimental structure of the A chain of the Escherichia coli enzyme (PDB 3BIC), showing missing amino acids in the truncated protein. MCM is shown as a ribbon model in orange, and missing amino acids are shown in light gray. The MCM nucleotide-binding site is shown as a cartoon representation, bound with guanosine diphosphate (in sticks). Case mutated residues discussed in this paper are shown as a ribbon model in violet. dose of L-carnitine and presented good metabolic control, but ultimately died from cardiomyopathy. The pathogenesis of cardiomyopathy in our case remains unclear. The patient did not show any infection signs such as fever and grunting. However, de Keyzer et al. [19] suggested mitochondrial oxidative phosphorylation impairment as an additional mechanism to intoxication causes energetic-dependent cardiomyopathy in patients with MMA. Therefore, physicians should consider the potential of cardiac complication in these patients with MMA.

In summary, this is the first case with MMA and cardiomyopathy in Korea that was confirmed by genetic analysis to involve a novel MUT gene mutation. Further studies are required to understand the functional changes of proteins involved in this disorder and their associations with the phenotypic spectrum.

\section{Acknowledgements}

We thank the patient and her family for participating in this study. This work was supported by a 2-Year Research Grant of Pusan National University.

\section{References}

1. Dionisi-Vici C, Deodato F, Röschinger W, Rhead W, Wilcken B. 'Classical' organic acidurias, propionic aciduria, methylmalonic aciduria and isovaleric aciduria: long-term outcome and effects of expanded newborn screening using tandem mass spectrometry. J Inherit Metab Dis 2006;29:383-9.

2. Deodato F, Boenzi S, Santorelli FM, Dionisi-Vici C. Methylmalonic and propionic aciduria. Am J Med Genet C Semin Med Genet 2006;142C:104-12.

3. Lerner-Ellis JP, Tirone JC, Pawelek PD, Doré $C$, Atkinson JL, Watkins $D$, et al. Identification of the gene responsible for methylmalonic aciduria and homocystinuria, cblC type. Nat Genet 2006;38:93-100.

4. Fowler B, Leonard JV, Baumgartner MR. Causes of and diagnostic approach to methylmalonic acidurias. J Inherit Metab Dis 2008;31:35060.

5. Hörster $F_{1}$ Baumgartner MR, Viardot $C$, Suormala $T$, Burgard $P$, Fowler $B$, et al. Long-term outcome in methylmalonic acidurias is influenced by the underlying defect (mut0, mut-, cblA, cblB). Pediatr Res 2007;62:225-30.

6. Prada $C E$, Al Jasmi F, Kirk EP, Hopp M, Jones O, Leslie ND, et al. Cardiac disease in methylmalonic acidemia. J Pediatr 2011;159:862-4.

7. Fujisawa $D$, Nakamura $K$, Mitsubuchi $H_{1}$ Ohura $T$, Shigematsu $Y_{1}$

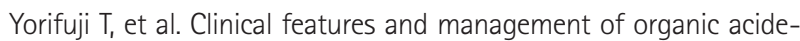
mias in Japan. J Hum Genet 2013;58:769-74. 
8. Cheng KH, Liu MY, Kao CH, Chen YJ, Hsiao KJ, Liu T, et al. Newborn screening for methylmalonic aciduria by tandem mass spectrometry: 7 years' experience from two centers in Taiwan. J Chin Med Assoc 2010;73:314-8

9. Jung JW, Hwang IT, Park JE, Lee EH, Ryu KH, Kim SH, et al. Mutation analysis of the MCM gene in Korean patients with MMA. Mol Genet Metab 2005;84:367-70.

10. Lee EH, Ko JM, Kim JM, Yoo HW. Genotype and clinical features of Korean patients with methylmalonic aciduria and propionic aciduria. Korean J Pediatr 2008;51:964-70.

11. Kwak MJ, Kim YM. A novel mutation in the mut gene in an asymptomatic newborn with isolated methylmalonic acidemia. J Korean Soc Inher Metab Dis 2014;14:174-7.

12. Song WS, Song BJ, Park HD, Kim WD. A novel MUT gene mutation detected in a female infant with methylmalonic acidemia. Neonatal Med 2015;22:51-4.

13. Mikami H, Ogasawara M, Matsubara Y, Kikuchi M, Miyabayashi S, Kure $S$, et al. Molecular analysis of methylmalonyl-CoA mutase deficiency: identification of three missense mutations in mut0 patients. J Hum Genet 1999;44:35-9.

14. Janata J, Kogekar N, Fenton WA. Expression and kinetic characteriza- tion of methylmalonyl-CoA mutase from patients with the mutphenotype: evidence for naturally occurring interallelic complementation. Hum Mol Genet 1997;6:1457-64.

15. Kobayashi $A$, Kakinuma $H$, Takahashi $H$. Three novel and six common mutations in 11 patients with methylmalonic acidemia. Pediatr Int 2006;48:1-4.

16. Ogasawara $M$, Matsubara $Y$, Mikami $H$, Narisawa $K$. Identification of two novel mutations in the methylmalonyl-CoA mutase gene with decreased levels of mutant mRNA in methylmalonic acidemia. Hum Mol Genet 1994;3:867-72.

17. Worgan LC, Niles K, Tirone JC, Hofmann A, Verner A, Sammak A, et al Spectrum of mutations in mut methylmalonic acidemia and identification of a common Hispanic mutation and haplotype. Hum Mutat 2006;27:31-43.

18. Azar MR, Shakiba M, Tafreshi RI, Rashed MS. Heart failure in a patient with methylmalonic acidemia. Mol Genet Metab 2007:92:188.

19. de Keyzer Y, Valayannopoulos V, Benoist JF, Batteux F, Lacaille F, Hubert $L_{1}$ et al. Multiple OXPHOS deficiency in the liver, kidney, heart, and skeletal muscle of patients with methylmalonic aciduria and propionic aciduria. Pediatr Res 2009;66:91-5. 